\title{
Sekundarna prevencija i rehabilitacija
}

\author{
Miodrag Ostojić
}

Klinika za kardiologiju, Klinički centar Srbije; Medicinski fakultet, Univerzitet u Beogradu

ekundarna prevencija i rehabilitacija predstavljaju esencijalni i dokazani deo lečenja bolesnika sa IBS, sa kojom se započinje još u bolničkim uslovima, i podrazumeva OMT, modifikaciju faktora rizika i permanentne promene stila života (prema već navedenoj formuli „0-3-5-120-4-2-0“ i Tabeli 1). Potrebna je evaluacija da li se bolesnici pridržavaju predloženih mera u redovnim vremenskim intervalima, na svakih 6 meseci.

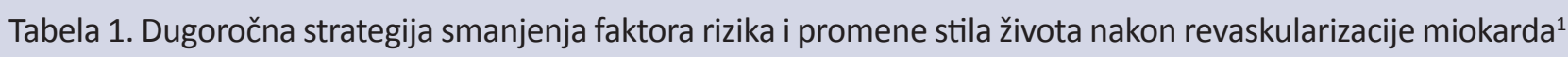

\begin{tabular}{|c|c|c|}
\hline & $\begin{array}{c}\text { Klasa } \\
\text { preporuke }\end{array}$ & $\begin{array}{l}\text { Nivo } \\
\text { dokaza }\end{array}$ \\
\hline \multicolumn{3}{|l|}{ Dugoročna strategija se bazira na stratifikaciji rizika koja obuhvata: } \\
\hline - detaljnu kliničku eveluaciju i fizikalni pregled & 1 & C \\
\hline - EKG & 1 & $\mathrm{~B}$ \\
\hline - laboratorijske testove & I & B \\
\hline - HbA1c & 1 & A \\
\hline - fizička aktivnost prema anamnezi i testu opterećenja & 1 & B \\
\hline - ehokardiogram pre i posle CABG & 1 & $\mathrm{C}$ \\
\hline Ehokardiografski pregled je potrebno razmotriti pre ili posle $\mathrm{PCl}$ & Ila & $\mathrm{C}$ \\
\hline $\begin{array}{l}\text { Savetovanje u vezi fizičke aktivnosti treba da obuhvati najmanje 30-60 min umereno } \\
\text { intenzivne aerobne aktivnosti dnevno }\end{array}$ & I & A \\
\hline $\begin{array}{l}\text { Programi sa medicinskom supervizijom su preporučljivi za visoko rizične bolesnike (npr. } \\
\text { skorašnja revaskularizacija, srčana insuficijencija) }\end{array}$ & I & B \\
\hline Vežbanje dva puta nedeljno može se uzeti u obzir & $\mathrm{Ilb}$ & C \\
\hline $\begin{array}{l}\text { Dijeta i kontrola težine treba da budu usmereni } \mathrm{ka} \mathrm{BMI}<25 \mathrm{~kg} / \mathrm{m}^{2} \text { i obimu struka }<94 \mathrm{~cm} \text { kod } \\
\text { muškaraca } \mathrm{i}<80 \mathrm{~cm} \text { kod žena }\end{array}$ & 1 & B \\
\hline $\begin{array}{l}\text { Preporučuje se merenje BMI i/ili obima struka pri svakoj poseti lekaru i da se konstantno } \\
\text { ohrabruje održavanje/redukcija telesne težine }\end{array}$ & I & B \\
\hline Inicijalni cilj terapije za redukciju telesne težine je oko $10 \%$ od početne & 1 & $\mathrm{~B}$ \\
\hline Preporučuje se izbor zdrave hrane & I & B \\
\hline Preporučuje se dijeta i promena stila života & 1 & B \\
\hline Preporučuje se dostizanje LDL holesterola $<2,5 \mathrm{mmol} / \mathrm{L}$ & $\mathrm{I}$ & A \\
\hline Kod visokorizičnih bolesnika preporučuje se dostizanje LDL holesterola $<2,0 \mathrm{mmol} / \mathrm{L}$ & 1 & B \\
\hline Povećano unošenje omega-3 masnih kiselina u obliku ribljeg ulja može se razmotriti & $\mathrm{Ilb}$ & B \\
\hline $\begin{array}{l}\text { Preporučuje se implementiranje promene stila života i farmakoterapija sa ciljem dostizanja } \\
\text { krvnog pritiska }<130 / 80 \mathrm{mmHg}\end{array}$ & I & A \\
\hline Beta blokatori i/ili ACE inhibitori su indikovani kao prva linija terapije & 1 & A \\
\hline $\begin{array}{l}\text { Preporučuje se da se na svakoj viziti lekaru razgovara o pušenju i da se insistira na prestanku } \\
\text { pušenja i izbegavanju pasivnog pušenja }\end{array}$ & 1 & B \\
\hline \multicolumn{3}{|l|}{ Kod bolesnika sa dijabetesom preporučuje se: } \\
\hline Promene stila života i farmakoterapija kako bi se dostigao $\mathrm{HbA} 1 \mathrm{c}<6,5 \%$ & 1 & B \\
\hline Agresivna modifikacija drugih faktora rizika & 1 & $\mathrm{~B}$ \\
\hline Koordinacija tretmana dijabetesa sa lekarom specijalistom & 1 & $\mathrm{C}$ \\
\hline Skrining za psihološki distres je indikovan & 1 & C \\
\hline Godišnja vakcinacija protiv gripa je indikovana & 1 & B \\
\hline
\end{tabular}


Kod bolesnika lečenih pomoću $\mathrm{PCl}$, za procenu rehabilitacionog programa sa fizičkim vežbanjem, simptomograničavajući test opterećenja je bezbedno izvesti 7-14 dana nakon $\mathrm{pPCl}$ i nakon $24 \mathrm{~h}$ kod elektivnih $\mathrm{PCl}$.
U Tabeli 2 prikazane su preporuke za OMT nakon revaskularizacije miokarda.

Tabela 2. Dugoročna medikamentna terapija nakon revaskularizacije miokarda

\begin{tabular}{|c|c|c|}
\hline & $\begin{array}{c}\text { Klasa } \\
\text { preporuke }\end{array}$ & $\begin{array}{l}\text { Nivo } \\
\text { dokaza }\end{array}$ \\
\hline $\begin{array}{l}\text { Potrebno je započeti i trajno nastaviti terapiju ACE inhibitorima kod svih bolesnika sa EF } \leq 40 \% \text {, } \\
\text { kao i kod bolesnika sa hipertenzijom, dijabetesom ili hroničnom bubrežnom insuficijencijom, } \\
\text { ukoliko ne postoje kontraindikacije }\end{array}$ & I & A \\
\hline ACE inhibitore treba razmotriti kod svih bolesnika, ukoliko ne postoje kontraindikacije & Ila & A \\
\hline $\begin{array}{l}\text { Antagonisti angiotenzinskih receptora su indikovani kod bolesnika koji ne tolerišu ACE } \\
\text { inhibitore i koji imaji srčanu insuficijenciju ili infarkt miokarda sa EF } \leq 40 \%\end{array}$ & I & A \\
\hline $\begin{array}{l}\text { Antagoniste angiotenzinskih receptora treba razmotriti kod svih bolesnika koji ne tolerišu ACE } \\
\text { inhibitore }\end{array}$ & Ila & A \\
\hline $\begin{array}{l}\text { Indikovano je započeti i nastaviti terapiju beta blokatorima kod svih bolesnika nakon infarkta } \\
\text { miokarda ili AKS ili sa disfunkcijom LK, ukoliko ne postoje kontraindikacije }\end{array}$ & 1 & A \\
\hline $\begin{array}{l}\text { Visoke doze lekova za snižavanje lipida su indikovane kod svih bolesnika, bez obzira na nivo } \\
\text { lipida, ukoliko ne postoje kontraindikacije }\end{array}$ & I & A \\
\hline $\begin{array}{l}\text { Fibrate i omega-3 masne kiseline ( } 1 \mathrm{~g} \text { dnevno) treba razmotriti u kombinaciji sa statinima ili } \\
\text { kod bolesnika koji ne tolerišu statine }\end{array}$ & Ila & B \\
\hline Niacin se može razmotriti za podizanje nivoa HDL holesterola & $\mathrm{Ilb}$ & B \\
\hline
\end{tabular}

\section{Literatura:}

1. Wijns W., et al. Guidelines on myocardial revascularization: The Task Force on Myocardial Revascularization of the European Society of Cardiology (ESC) and the European Association for CardioThoracic Surgery (EACTS). Eur Heart J., 2010; 31 (20): 2501-55. 